Article

\title{
In Vitro, in Situ and in Vivo Studies on the Anticandidal Activity of Cassia fistula Seed Extract
}

\author{
Subramanion L. Jothy ${ }^{1,2}$, Zuraini Zakariah ${ }^{1}$, Yeng Chen ${ }^{3, *}$ and Sreenivasan Sasidharan ${ }^{2, *}$ \\ 1 Biological Program, School of Distance Education, Universiti Sains Malaysia, Minden 11800, \\ Penang, Malaysia \\ 2 Institute for Research in Molecular Medicine (INFORMM), Universiti Sains Malaysia, \\ Minden 11800, Pulau Pinang, Malaysia \\ 3 Dental Research and Training Unit, and Oral Cancer Research and Coordinating Centre (OCRCC), \\ Faculty of Dentistry, University of Malaya, Kuala Lumpur 50603, Malaysia \\ * Authors to whom correspondence should be addressed; E-Mails: chenyeng@um.edu.my (Y.C.); \\ srisasidharan@yahoo.com (S.S.); Tel.: +60-37-967-4800 (Y.C.).
}

Received: 24 April 2012; in revised form: 23 May 2012 / Accepted: 25 May 2012 /

Published: 7 June 2012

Abstract: Cassia fistula seeds have many therapeutic uses in traditional medicine practice. The present investigation was undertaken to demonstrate the anticandidal activity of the C. fistula seed extract at ultra-structural level through transmission electron microscope (TEM) and scanning electron microscope (SEM) observations. The effect of seed extract on the growth profile of the Candida albicans was examined via time-kill assays and in vivo efficacy of the extract was tested in an animal model. In addition, the anticandidal effect of seed extract was further evaluated by microscopic observations using SEM and TEM to determine any major alterations in the ultrastructure of $C$. albicans. The complete inhibition of $C$. albicans growth was shown by $C$. fistula seed extract at $6.25 \mathrm{mg} / \mathrm{mL}$ concentration. The time-kill assay suggested that $C$. fistula seed extract had completely inhibited the growth of $C$. albicans and also exhibited prolonged anti-yeast activity. The SEM and TEM observations carried out to distinguish the metamorphosis in the morphology of control and C. fistula seed extract-treated C. albicans cells revealed the notable effect on the outer cell wall and cytoplasmic content of the $C$. albicans and complete collapse of yeast cell exposed to seed extract at concentration $6.25 \mathrm{mg} / \mathrm{mL}$ at $36 \mathrm{~h}$. The in vitro time-kill study performed using the leaf extract at $1 / 2,1$ or 2 times of the MIC significantly inhibited the yeast growth with a noticeable drop in optical density (OD) of yeast culture, thus confirming the fungicidal effect of the extract on C. albicans. 
In addition, in vivo antifungal activity studies on candidiasis in mice showed a 6-fold decrease in C. albicans in kidneys and blood samples in the groups of animals treated with the extract $(2.5 \mathrm{~g} / \mathrm{kg}$ body weight). The results suggested that the $C$. fistula seed extract possessed good anticandidal activity and is a potential candidate for the development of anticandidal agents.

Keywords: Candida albicans; Cassia fistula seed; anticandidal activity; scanning electron microscope; transmission electron microscope

\section{Introduction}

Cassia fistula Linn. (Leguminosae) is cultivated widely throughout Malaysia as an ornamental and deciduous plant. It is also being cultivated in the tropics, including in the West Indies, Ceylon, China, Egypt and many other countries. As a medicinal plant it is used mainly in the West Indies, namely Dominica and Martinique [1]. "Purging cassia" was known in Europe in the thirteenth century and was used by the School of Medicine at Salerno [2]. In Ayurvedic medicine, this plant is used for a treatment of hematemesis, pruritus, leucoderma and diabetes. The juice of the leaf is given for erysipelas and skin diseases [3]. In Sri Lanka, this plant is used for skeletal fractures [4]. Moreover, different parts of this plant have been demonstrated to possess several pharmacological activities such as antitumor [5], antioxidant [6], hypoglycemic [7], hepatoprotective [8], antibacterial [9], hypocholesterolaemic [10], and antidiabetic [11].

Oral candidiasis is the most common opportunistic infection associated with HIV/AIDS, with up to 90\% of HIV-infected individuals [12]. Candida albicans is the most frequent etiological strain associated with this infection and reminds the predominant strain in most of the countries. The antifungals prescribed for treating oral candidiasis in HIV-positive patients in long-term therapy has led to the development of resistance $[13,14]$. In this perspective, new agents from natural resources that can inhibit the growth of $C$. albicans are greatly needed and would enhance the effectiveness of the therapy. Our previous study showed that the methanol extract of $C$. fistula seed extract possessed a good anticandidal activity against $C$. albicans with minimum inhibition concentration (MIC) value of $6.25 \mathrm{mg} / \mathrm{mL}$ [15]. The present investigation demonstrates the anticandidal activity of the C. fistula seed extract at ultra-structural level through TEM and SEM observations at $6.25 \mathrm{mg} / \mathrm{mL}$ concentration with in vitro time killing and in vivo animal studies.

\section{Results}

\subsection{Time-Kill Study}

The result obtained from the previous study indicated that $C$. fistula seed extract showed anticandidal activity. The MIC of the $C$. fistula seed extract in broth dilution method was found to be $6.25 \mathrm{mg} / \mathrm{mL}$. Time-kill studies were performed over a period of $48 \mathrm{~h}$ with yeast being exposed to $1,1 / 2$ or $2 \times$ MIC of the $C$. fistula seed extract. The result of the time-kill curves for $C$. albicans is shown in Figure 1. At 1/2 $\times$ MIC, C. fistula seed extract demonstrated a large drop in Optical Density (OD) after 
$16 \mathrm{~h}$, which leads to the stationary phase of yeast growth compared with the control. At MIC and $2 \times$ MIC, C. fistula seed extract produced absolute yeast eradication after only $4 \mathrm{~h}$. The time-kill curves described above show the potency of $C$. fistula seed extract as an anticandidal agent against $C$. albicans.

Figure 1. Growth profile of Candida albicans in Muller Hinton broth with 0 (control) and $3.13 \mathrm{mg} / \mathrm{mL}$ (1/2 MIC), $6.25 \mathrm{mg} / \mathrm{mL}$ (MIC) and $12.5 \mathrm{mg} / \mathrm{mL}$ (2 MIC) concentration of C. fistula seed extract.

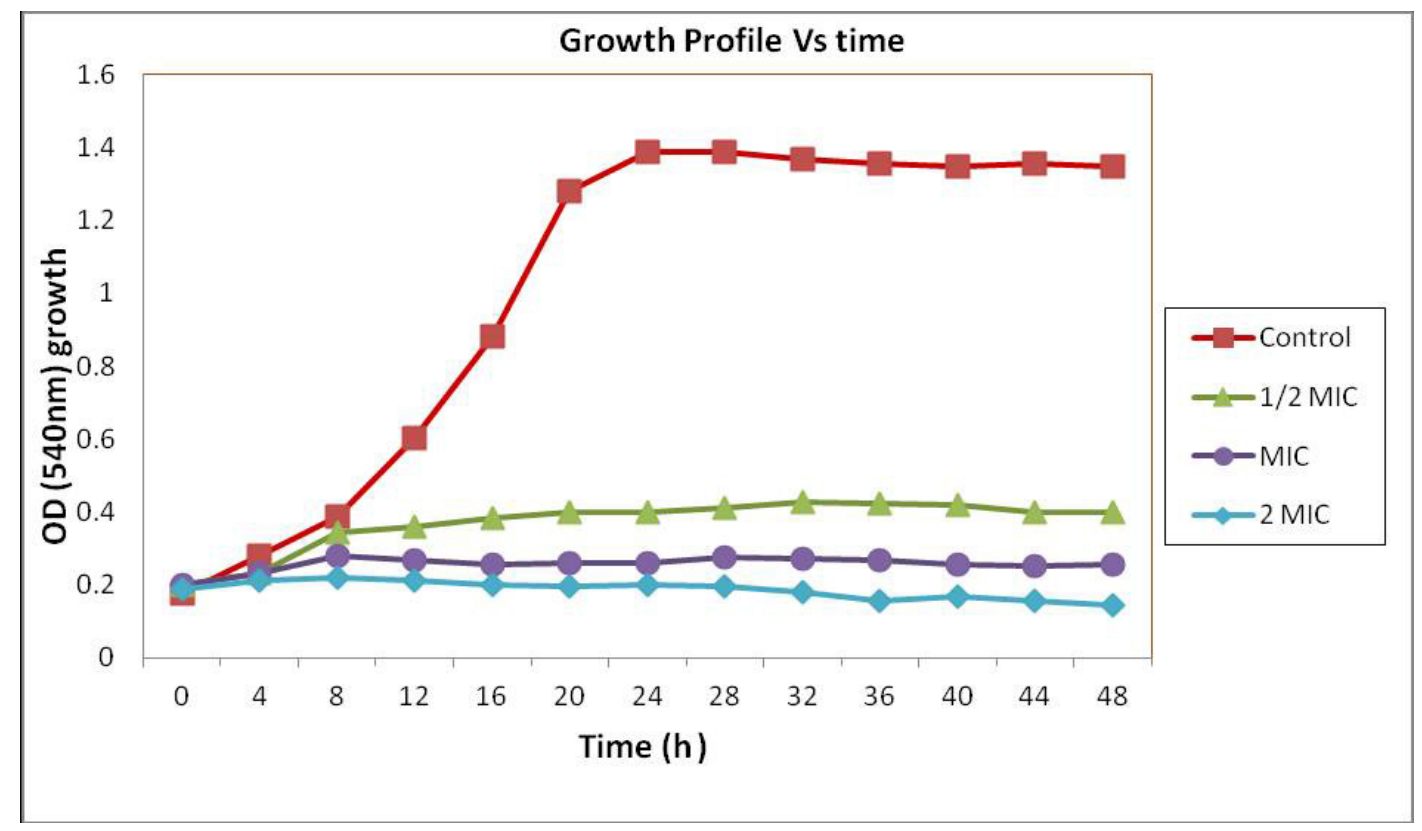

\subsection{Scanning Electron Microscopy (SEM)}

Figure 2 shows SEM photomicrographs of the untreated and extract treated cells of $C$. albicans at various times of exposure to the crude extract of $C$. fistula. Untreated control cells (Figure 2a) showed many regular, homogeneous cells with smooth walls in appearance and some at a budding stage. After $12 \mathrm{~h}$ of exposure (Figure $2 \mathrm{~b}$ ), a mild effect of the extract was observed and elongated cells also appeared. The $24 \mathrm{~h}$ treated cells (Figure 2c) had a rough appearance with holes compared to the untreated control cells with the formation of invaginations. The surface of the $C$. fistula treated cells also appeared uniformly rough because of a well-defined wrinkling of the cell wall. Moreover, the yeast cells were present in clusters of interconnected cells. After $36 \mathrm{~h}$ of exposure (Figure 2d), completely collapsed or cavitated cells with rough in appearance surfaces with holes were seen. Huge amounts of vesicular material were equally found scattered in between the C. albicans cells. These materials were clearly seen in the $36 \mathrm{~h}$ treated group (Figure 2d), was most likely derived from broken cells and presented membrane-limited cytoplasmic leftovers. The remaining unbroken C. albicans cells showed a smooth surface as observed in untreated control cells. 
Figure 2. Scanning electron microscope photomicrograph of the untreated (a) and extract-treated (b,c,d) cells of Candida albicans.
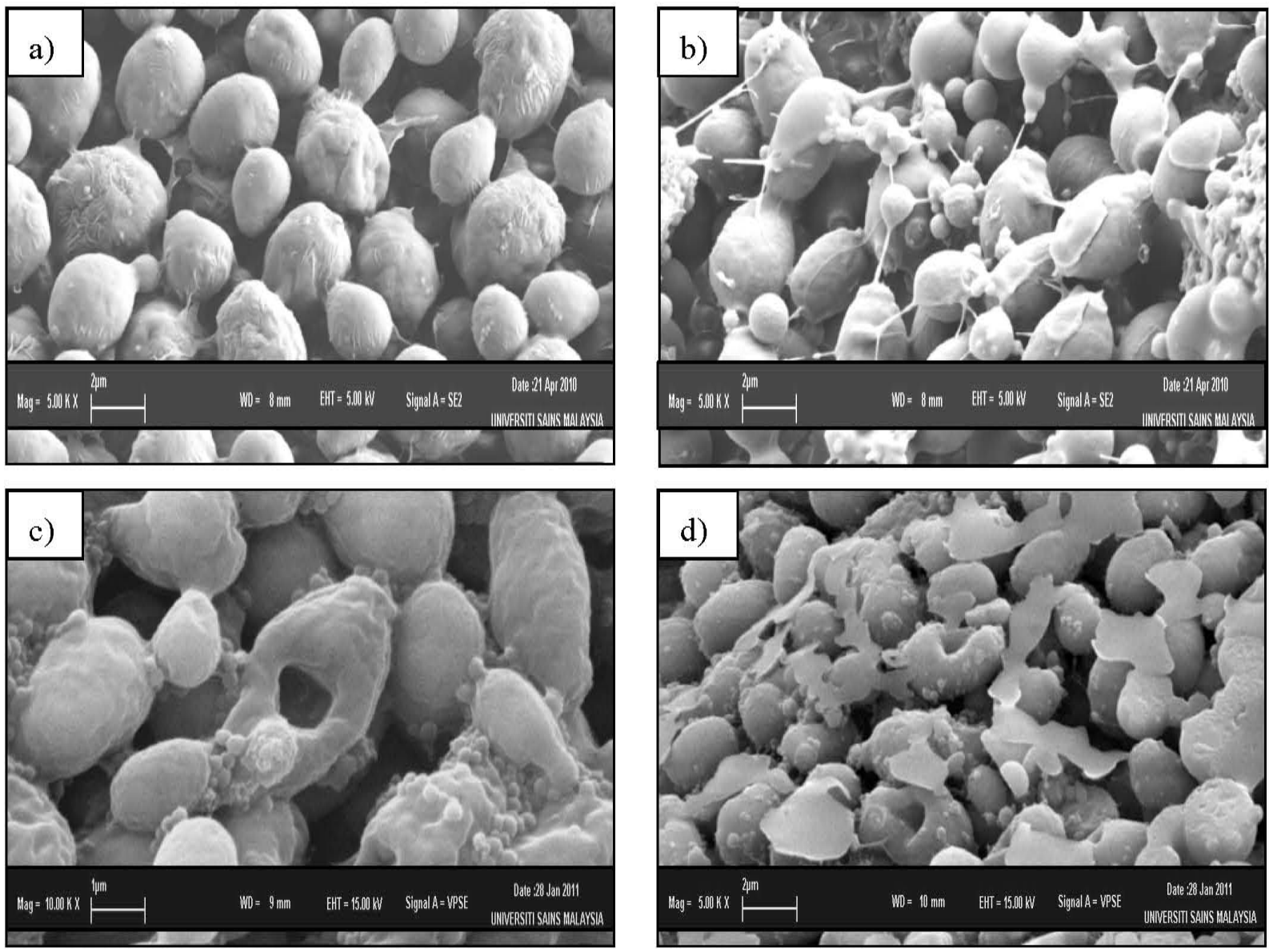

\subsection{Transmission Electron Microscope (TEM)}

The SEM findings, suggested that the methanol extract of $C$. fistula can caused severe alteration in the morphology of $C$. albicans. Further evidence of anticandidal activity was obtained from a TEM study. Figure 3 shows the TEM photomicrographs of the longitudinal and transverse sections of the untreated control cells of $C$. albicans. The cytoplasm of $C$. albicans cells appeared homogeneous containing a nucleus, vesicle and mitochondria, surrounded by a defined cell membrane and regular cell wall with a clear periplasm region. After $12 \mathrm{~h}$ of exposure to the $C$. fistula extract (Figure 4), the cell was very densed with the vesicles and membranous bodies dispositioned within the cell. After $24 \mathrm{~h}$ of exposure (Figure 5), the cells showed shrinkage of the protoplast, disruption of the cytoplasmatic membrane and notable alterations in the cell wall. The cytoplasmic volume decreased and the cell membrane invaginated with notable structural disorganization within the cell cytoplasm. It seems that the extract induced dysfunctions of the cell membrane. Figure 6 shows the significant effect of the extract on the yeast cells after $36 \mathrm{~h}$ of exposure. All the inner organelles were completely discomposed and even cell membrane and wall were deeply affected and look like undulant. Yeast cells were found collapsed which followed by an outflow of the cytoplasmic component (Figure 6). 
Figure 3. TEM micrograph of a cross-section of untreated cell of Candida albicans (C: Cytoplasm; CW: Cell Wall; M: Mitochondria; N: Nucleus; V: Vacuole).
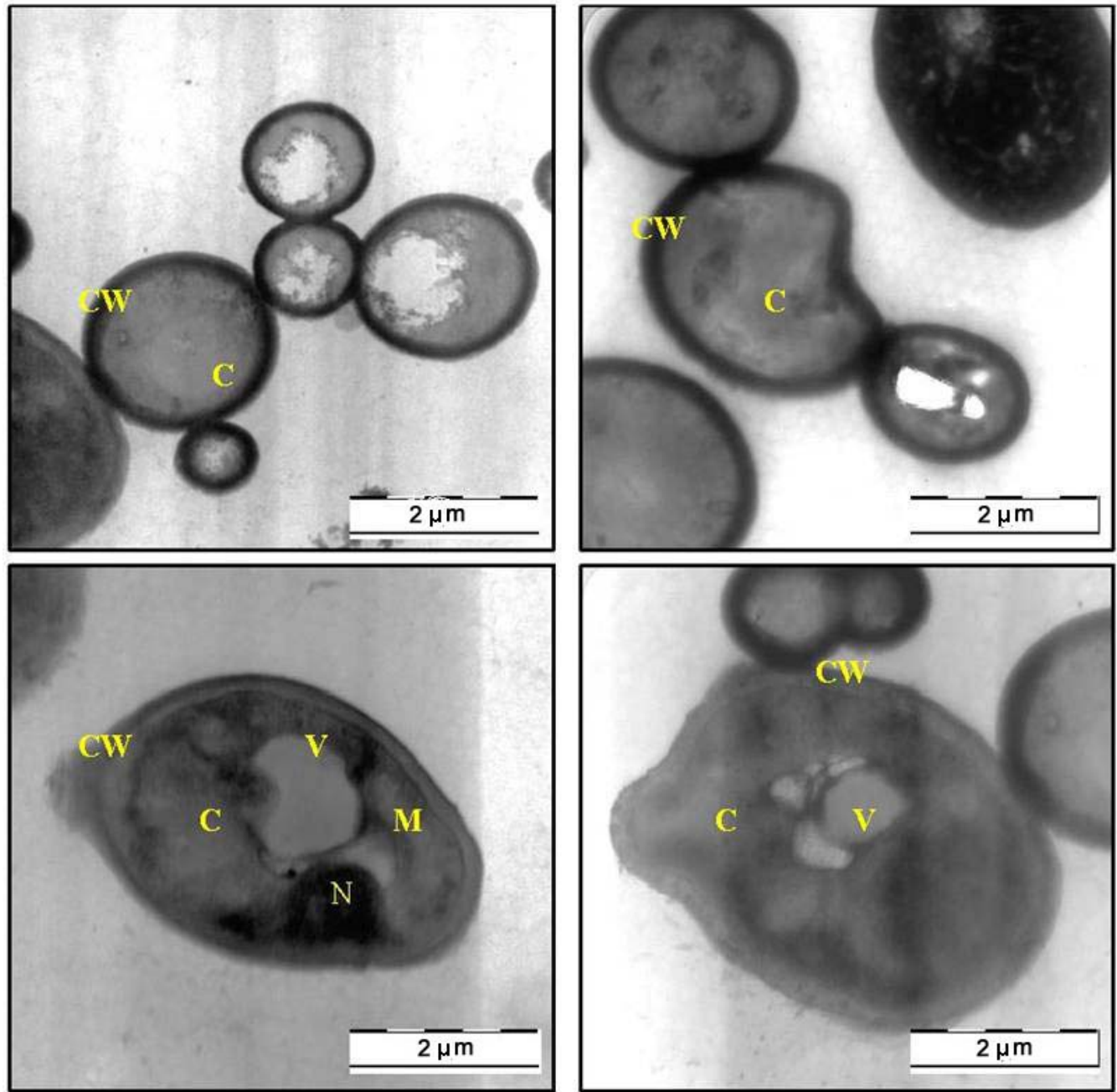

Figure 4. TEM micrograph of a cross-section of the extract treated cell of Candida albicans after 12 h (C: Cytoplasm; CW: Cell Wall; N: Nucleus; V: Vacuole).
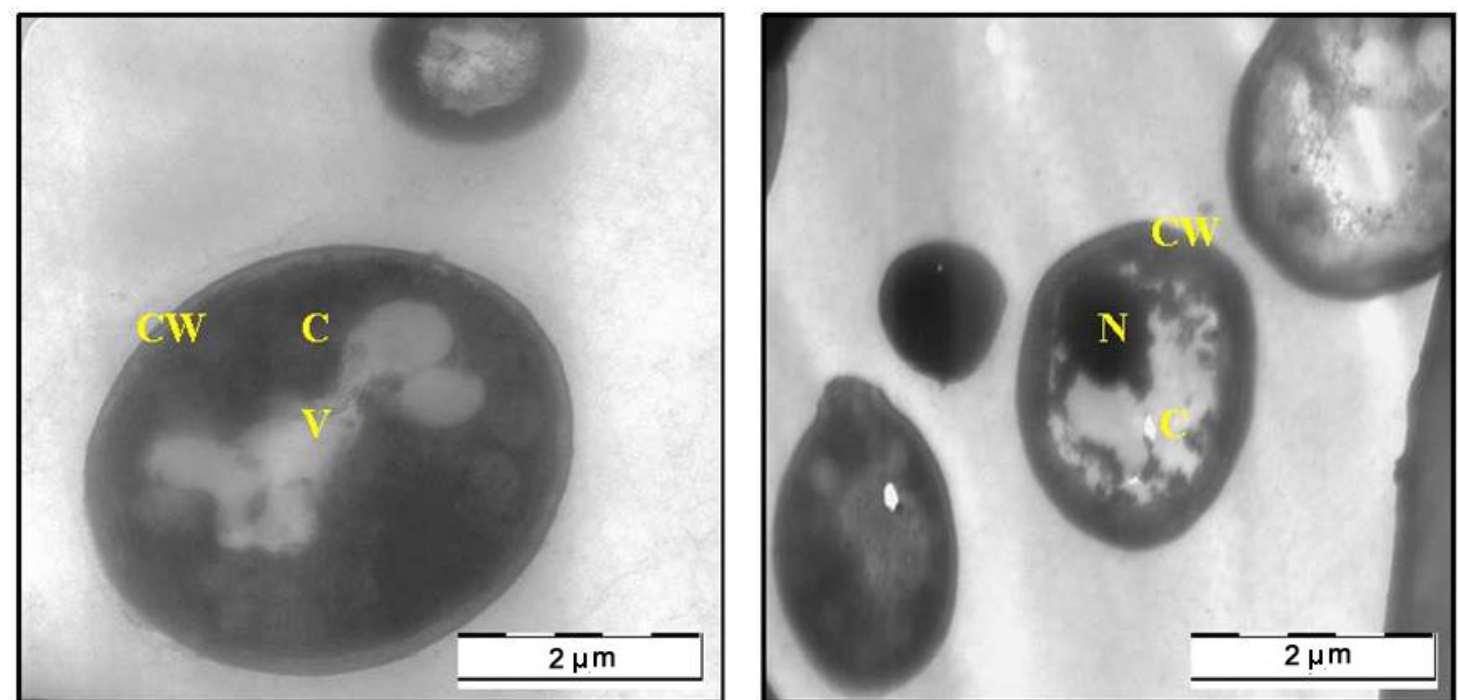
Figure 4. Cont.
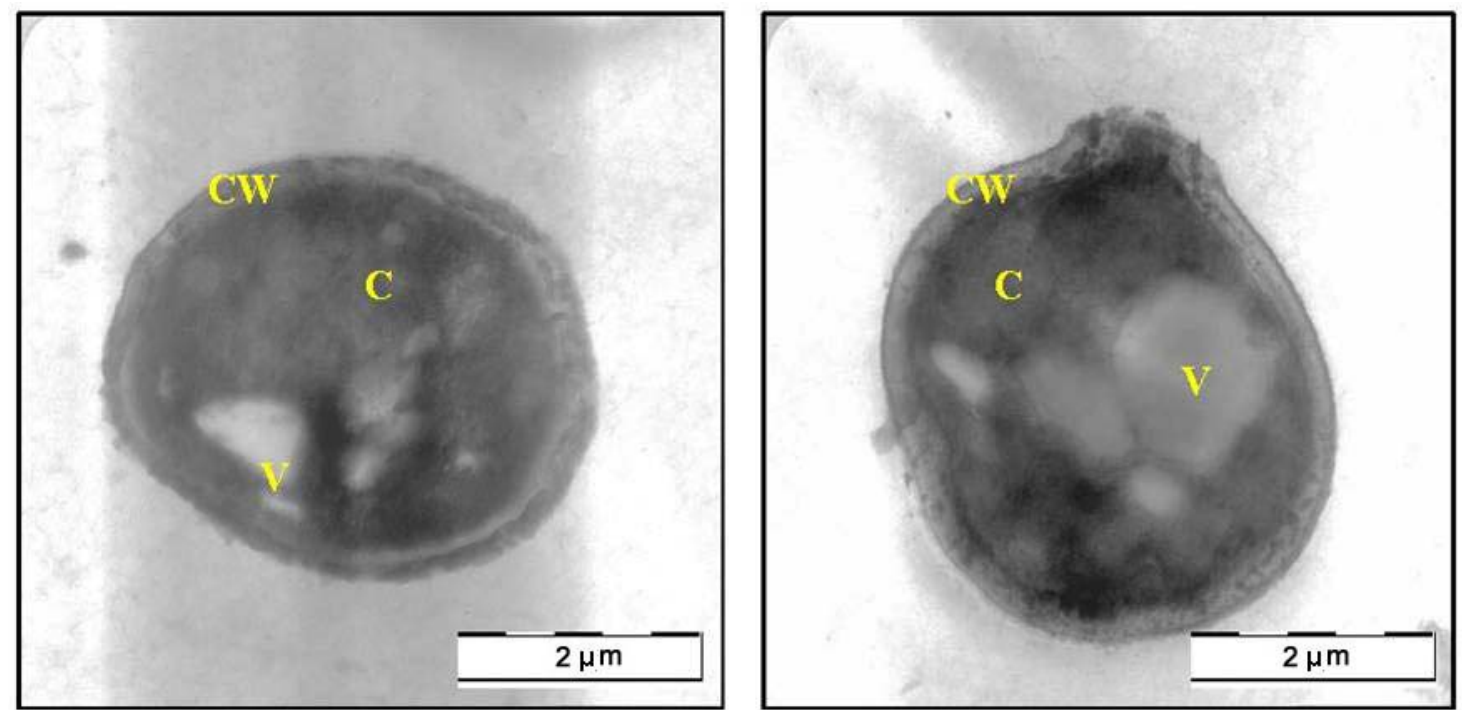

Figure 5. TEM micrograph of a cross-section of the extract treated cell of Candida albicans after $24 \mathrm{~h}$ (C: Cytoplasm; CW: Cell Wall; M: Mitochondria; V: Vacuole).
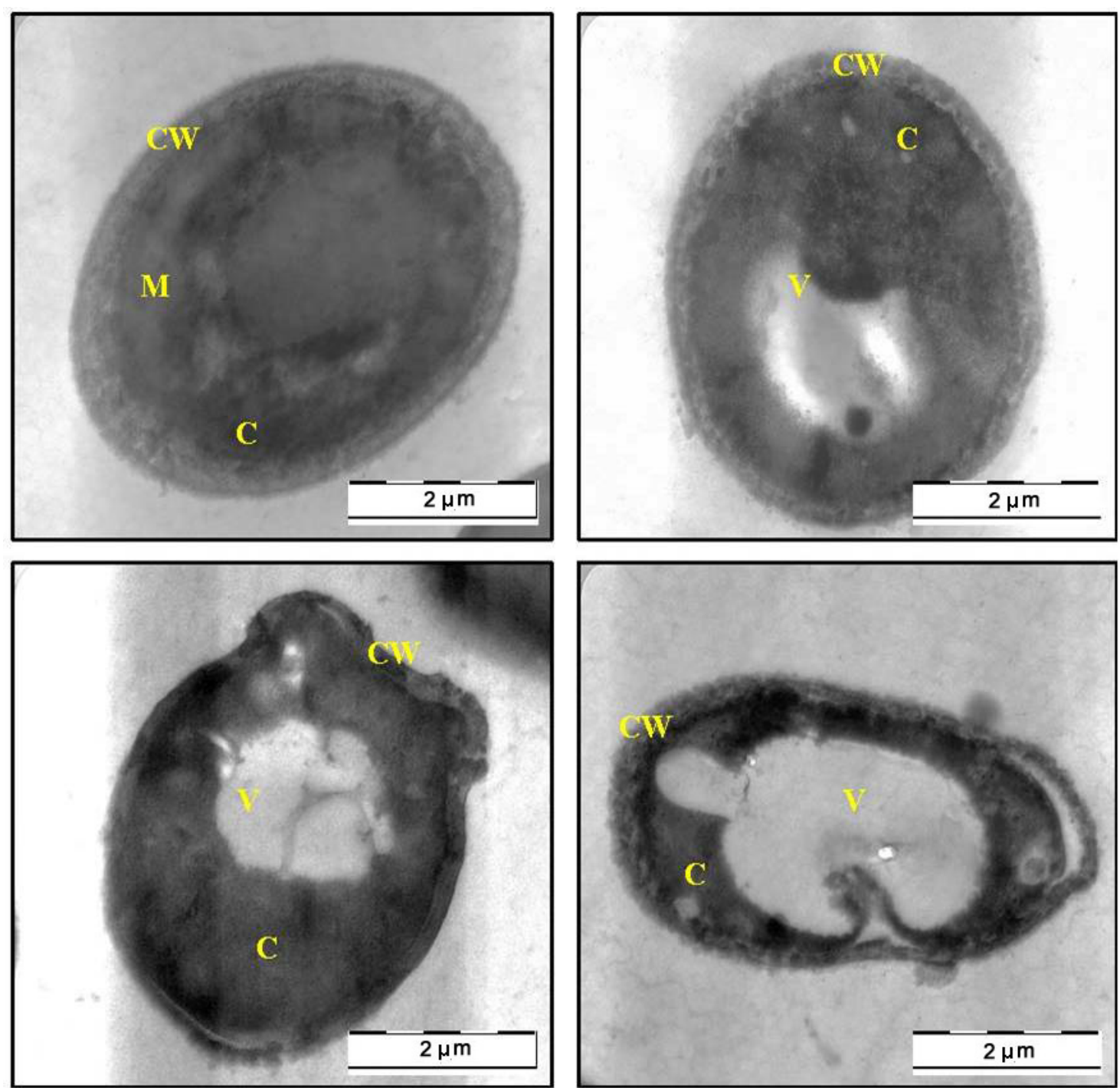
Figure 6. TEM micrograph of a cross-section of the extract treated cell of Candida albicans after 36 h (C: Cytoplasm; CW: Cell Wall).
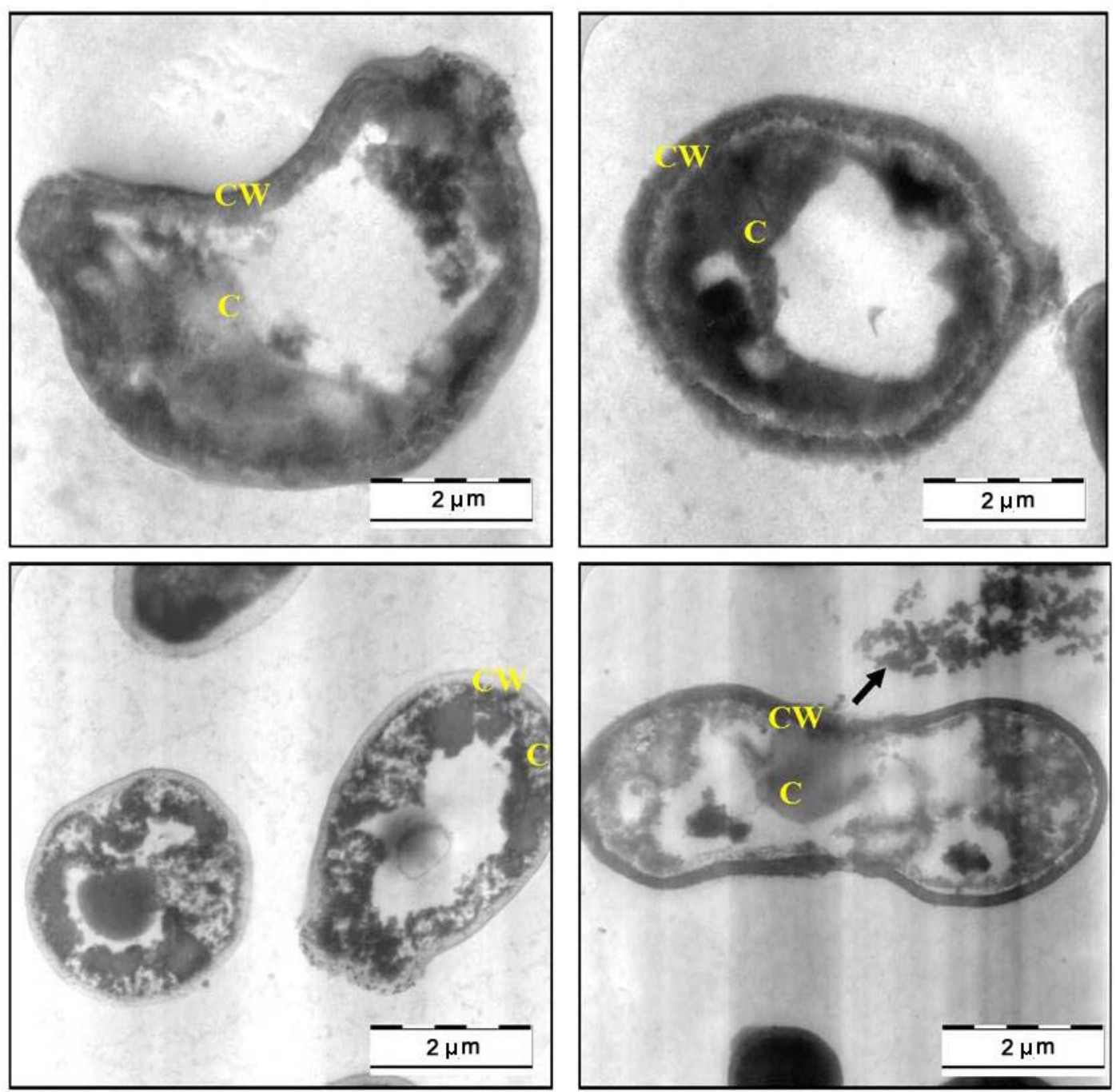

\subsection{In Vivo Antifungal Activity}

Table 1 shows the mean of CFU/g organ and CFU/mL of blood from the two groups. In Group 2 animals that received a $2.5 \mathrm{~g} / \mathrm{kg}$ body weight dose of the plant extract followed by inoculation of C. albicans, a significant reduction $(p<0.05)$ in CFU was observed in kidney and blood samples studied. A 6-fold difference was present in the kidney and blood samples of the treated group compared with those of the control group.

Table 1. Effect of methanolic extract of Cassia fistula seed on Candida albicans recovered from kidney and blood of mice.

\begin{tabular}{lcc}
\hline \multicolumn{1}{c}{ Group } & Kidney (CFU/g) & Blood (CFU/mL of blood) \\
\hline Group 1 (control) i.v. Candida + i.p. PBS & $2.19 \times 10^{5} \pm 14,322$ & $2.76 \times 10^{5} \pm 11,725$ \\
Group 2 (curative) i.v. Candida + i.p. Extract & $3.87 \times 10^{4} \pm 73^{\mathrm{a}}$ & $4.68 \times 10^{4} \pm 47^{\mathrm{a}}$ \\
\hline
\end{tabular}

All values are colony-forming units (CFU/g organ or $\mathrm{CFU} / \mathrm{mL}$ of blood) expressed as mean \pm standard error of mean of 10 determinations. ${ }^{a} p<0.05$ compared with control (Student $t$-test). 


\section{Discussion}

C. fistula seed extract exhibited a favorable anti-yeast activity against $C$. albicans with a MIC value of $6.25 \mathrm{mg} / \mathrm{mL}$ [15]. The MIC value was defined as the lowest extract concentration that completely inhibited visible growth of $C$. albicans. Effectiveness of anti-yeast activity inversely correlated with their MIC values. Kuete et al. [16] reported that the extract having activities where the MIC values are below $8 \mathrm{mg} / \mathrm{mL}$ are considered to possess some antimicrobial activity. Time-kill assay was utilized in this study to verify MIC findings and to evaluate the ability of $C$. fistula seed extract to eliminate C. albicans growth in vitro. In the case of one- and two-times MIC concentrations, the extract inhibited the yeast growth within $4 \mathrm{~h}$ and subsequent regrowth was not seen.

The time-kill assay suggested that $C$. fistula extract completely inhibited the growth of $C$. albicans and it also exhibited prolonged anti-yeast activity against the $C$. albicans as determined by time-kill curves. These results hypothesised that the phytochemicals of $C$. fistula seed extract attacked the C. albicans cells and caused higher cell damage. To verify this hypothesis, $C$. albicans cells (untreated and $C$. fistula seed extract treated) were observed through different microscopic techniques. In this study, the methanolic extract of $C$. fistula seed was shown to have significant anticandidal activity in an animal model when given by intraperitoneal injection followed by inoculation of $C$. albicans, indicating a strong antifungal activity.

In this communication, we were especially interested in the mophogenesis of the $C$. albicans cells challenged by $C$. fistula seed extract. In vitro observation of anticandidal activity of $C$. fistula seed extract in this study was further evaluated by in situ microscopic method to postulate the possible mechanisms of action in $C$. albicans. The morphological observation of $C$. albicans cells treated with plant extract by using electron microscope is considering a gold standard technique to study the in situ anticandidal activity.

In this study, SEM and TEM observations were utilized to study the anticandidal activity of C. fistula seed extract. The SEM and TEM methods are advantageous over several other microscopic methods as they are 3-dimentional and almost the whole cell of the specimen is sharply focused [17]. The microscopic examination of $C$. albicans using SEM showed that the cells treated with $C$. fistula seed extract decreased in size, appeared irregular in shape with cell wall modifications and clear depressions on the cell surface with holes. Also, TEM observation showed irregular cell walls, ruptured cell membranes, unclear periplasm and dense cytoplasm without differentiated features. Such modifications may be related to the interference of the seed extract components with enzymatic reactions of wall synthesis which affects yeast morphogenesis and growth. The cytoplasmic membranes of yeast provide a barrier to the passage of small ions such as $\mathrm{H}^{+}, \mathrm{K}^{+}, \mathrm{Na}^{+}$and $\mathrm{Ca}^{2+}$ and allow cells and organelles to control the entry and exit of different compounds. This permeability barrier role of cell membranes is integral to many cellular functions, including the maintenance of the energy status of the cell, other membrane-coupled energy-transducing process, solute transport, regulation of metabolism and control of turgor pressure [18-20]. When cells of $C$. albicans were incubated with $C$. fistula seed extract, the leakage of ions from both treated and untreated cells were nearly the same within $12 \mathrm{~h}$. This implied that the extract had a little effect on the cells or their membranes during the first $12 \mathrm{~h}$. But within 12 to $36 \mathrm{~h}$, significant increase in $\mathrm{K}^{+}, \mathrm{Ca}^{2+}$ and $\mathrm{Mg}^{2+}$ leakage from treated cells might have occurred. For these ions $\left(\mathrm{K}^{+}, \mathrm{Ca}^{2+}\right.$ and $\left.\mathrm{Mg}^{2+}\right)$ to be released from 
the cells, some changes in the cell membrane may have occurred after treated with the extract. The exposure to the extract increased the permeability of plasma membrane by disrupting the permeability barrier of cell membrane structures accompanied by the loss of chemiosmotic control [21]. Hence, the effect of seed extract, on the $C$. albicans may attribute to the disruption of fungal membrane which was observed by SEM as damaged membrane accompanied by an important surface alteration.

The results from this study also agree with the suggestion by Prashar et al. [22] that the release of ions is not only based on their size and/or due to formation of holes or lesions of lipid bilayer of the plasma membrane of $C$. albicans but with various steps. Actually, the anticandidal action of $C$. fistula seed extract may happen in two steps. The first step involves the passive entry of the seed extract into the plasma membrane in order to initiate membrane disruption. The second stage is the accumulation of $C$. fistula seed extract in the plasma membrane resulting in the inhibition of cell growth [21]. Hence, C. fistula has the potential compounds with the above mentioned possible mechanisms which deserved further detailed studies.

\section{Experimental}

\subsection{Plant Collection}

Fresh pods of Cassia fistula were collected from various areas in Universiti Sains Malaysia, Penang in November, 2010 and authenticated by the botanist of the School of Biological Sciences at Universiti Sains Malaysia where the herbarium sample was deposited. The sun-dried pods are cut open and the seeds were removed from the pods. The seeds were then washed thoroughly and rinsed with tap water and dried in oven at $60{ }^{\circ} \mathrm{C}$ for three to four days. Then the dried seeds were homogenized to a fine powder and stored in airtight bottles.

\subsection{Preparation of the Crude Extracts}

The seed powder was sequentially extracted with methanol by adding approximately $100 \mathrm{~g}$ of the dried sample (in fine powder form) to $400 \mathrm{~mL}$ methanol. The extraction was carried out at room temperature by soaking for 7 days with intermittent stirring during the first day. The extracts were filtered through clean muslin cloth and the process of extraction was repeated again for a second time by adding another $400 \mathrm{~mL}$ of methanol to the sample residue. The filtrate from each extraction was combined and concentrated under vacuum by rotary evaporator (Büchi, Switzerland) at $40{ }^{\circ} \mathrm{C}$ to $50{ }^{\circ} \mathrm{C}$ in order to evaporate the excess methanol solvent and until a dark green methanol extract was produced. Then concentrated extract was poured in glass Petri plates and brought to dryness at $60{ }^{\circ} \mathrm{C}$ in the oven until a paste-like mass was obtained. Then paste form extract was sealed in Petri plates and stored at room temperature (RT). The crude extract was prepared by diluting the paste in methanol and stored in air-tight bottles at $4{ }^{\circ} \mathrm{C}$ for further studies.

\subsection{Microorganism}

Candida albicans strain (local clinical isolate) was used as the test organism and was obtained from a laboratory stock culture. The yeast was cultured on Sabouraud dextrose agar at $30{ }^{\circ} \mathrm{C}$ for $24 \mathrm{~h}$. The stock cultures were maintained on Sabouraud dextrose agar slants at $4{ }^{\circ} \mathrm{C}$. 


\subsection{Growth Profile of C. albicans in the Presence of C. fistula Seed Extract}

The Minimum Inhibitory Concentration (MIC) of extract against C. albicans was determined by using broth dilution method. In order to assess the anticandidal activity with MIC, 1/2 MIC, and 2 MIC concentration over time, growth profile curves were plotted [23]. A $16 \mathrm{~h}$ culture was harvested by centrifugation, washed twice with phosphate saline, and resuspended in phosphate saline. The suspension was adjusted using the McFarland standard and was then further diluted in phosphate saline to achieve approximately $10^{7} \mathrm{CFU} \mathrm{\textrm {mL } ^ { - 1 }}$. C. fistula seed extract was added to aliquots of $25 \mathrm{~mL}$ Mueller-Hinton broth (MHB) in a $50-\mathrm{mL}$ Erlenmeyer flask $\left(37^{\circ} \mathrm{C}\right)$ to achieve a concentration of 0 (control), $6.25 \mathrm{mg} / \mathrm{mL}$ (MIC), $3.13 \mathrm{mg} / \mathrm{mL}$ (1/2 MIC), and $12.5 \mathrm{mg} / \mathrm{mL}$ (2 MIC) after addition of the inocula. One $\mathrm{ml}$ of inocula was added to all Erlenmeyer flasks. Finally, $1 \mathrm{~mL}$ portion was removed and the growth of $C$. albicans was monitored using this portion by measuring optical density at $540 \mathrm{~nm}$ using UV-Visible spectrophotometer (UV-9100; Ruili Co., Beijing, China). The growth of C. albicans was measured every $4 \mathrm{~h}$ for $48 \mathrm{~h}$ continuously by the above method.

\subsection{Scanning Electron Microscopy (SEM) Observation}

Scanning electron microscope observations were carried out on C. albicans cells. One milliliter of C. albicans cell suspension at concentration $1 \times 10^{6}$ cells per milliliter was inoculated on Sabouraud Dextrose Agar plate and then incubated at $30^{\circ} \mathrm{C}$ for $6 \mathrm{~h}$. One milliliter of $6.25 \mathrm{mg} / \mathrm{mL}$, C. fistula seed extract was dropped onto inoculated agar and further incubated for $36 \mathrm{~h}$ at the same temperature. The cells which were not treated with extract were used as a control. A small block of yeast containing agar was withdrawn from plate at $0,12,24$ and $36 \mathrm{~h}$ placed on planchette and fixed for scanning (LEO SUPRA 50 VP Field Emission SEM, Carl Zeiss, Oberkochen, Germany) [24]. The SEM observation was done under the following analytical condition: $\mathrm{L}=\mathrm{SE} 1, \mathrm{EHT}=5.00 \mathrm{kV}$ and $\mathrm{WD}=8 \mathrm{~mm}$ to study the effect of extract on C. albicans cells.

\subsection{Transmission Electron Microscope (TEM) Observation}

Transmission Electron Microscope (TEM) observations were also carried out on C. albicans cells. The preparation procedure of $C$. albicans cells on plates was similar as described in SEM section. The TEM analyses were performed [24] on sample which were harvested at same hours (0, 12, 24 and $36 \mathrm{~h})$ and fixed in McDowell-Trump fixative prepared in 0.1 M phosphate solution ( $\mathrm{pH}$ 7.2), rinsed in buffer for three times, postfixed in $1 \%$ of osmium tetroxide in buffer for $2 \mathrm{~h}$ at $4{ }^{\circ} \mathrm{C}$ then the sample was serially dehydrated with $50 \%, 75 \%, 95 \%$ and $100 \%$ ethanol respectively and embedded in Epon- Araldite resin for making the blocks of the cells. The resin with the embedded $C$. albicans cells were cut into ultra thin sections in the ultramicrotomy process. Finally, the ultra-thin sections of the cells were stained with $2 \%$ uranyl acetate and lead citrate and observed under a Transmission Electron Microscope (TEM) (LIBRA 120-ZEISS, Oberkochen, Germany). 


\subsection{In Vivo Antifungal Activity}

\subsubsection{Laboratory Animals}

Swiss albino mice (male) weighing between 25 and $35 \mathrm{~g}$ were used. The cages with the mice were placed in a room (temperature $26 \pm 2{ }^{\circ} \mathrm{C}$ ) with controlled cycles of $12 \mathrm{~h}$ of light and $12 \mathrm{~h}$ of darkness; light went on at 7 am and relative humidity was $45-55 \%$. Water and food were provided to animals ad libitum. The experimental protocols were approved by the Institutional Animal Ethics Committee (IAEC) of the School of Pharmaceutical Sciences, Universiti Sains Malaysia. Experiments were conducted in accordance with the internationally accepted principles for laboratory animal use and care (USM/ Animal Ethics Approval/ 2010/ (59)(262)).

\subsubsection{Antifungal Assay}

The standard intravenous (i.v.) inoculation of $C$. albicans used in this study was $1 \times 10^{7}$ viable cells $/ \mathrm{mL}$ PBS, of which $0.1 \mathrm{~mL}$ was injected into the lateral tail vein of mice [25]. Animals were divided into two groups of 10 mice each and received treatment as described in Table 2. All mice were killed by cervical dislocation on day 5 after i.v. C. albicans inoculation.

Table 2. Details of experimental groups.

\begin{tabular}{cl}
\hline Group & \multicolumn{1}{c}{ Treatment } \\
\hline Group 1 (control) & $\begin{array}{l}\text { i.v. C. albicans: } 24 \mathrm{~h} \text { gap, followed by treatment with PBS (i.p. once } \\
\text { daily for 3 days) }\end{array}$ \\
Group 2 (curative) & $\begin{array}{l}\text { i.v. C. albicans: } 24 \mathrm{~h} \text { gap, followed by treatment with Cassia fistula } \text { seed } \\
\text { extract, 2.5 g/kg body weight (i.p. once daily for 3 days) }\end{array}$ \\
\hline & i.v., intravenous; i.p. intraperitoneal; PBS Phosphate buffer solution.
\end{tabular}

The kidneys of each animal were removed aseptically, and $0.1 \mathrm{~mL}$ of blood was withdrawn from the renal artery and $0.1 \mathrm{~mL}$ of heparin $(25 \mathrm{U} / \mathrm{mL})$, as an anticoagulant was added into the blood sample. The kidneys were then, placed in sterile centrifuge tubes and homogenized in $5 \mathrm{~mL}$ of sterile PBS. Aliquots from each homogenate and blood samples were serially diluted, plated on Sabouraud dextrose agar plates, and incubated at $37{ }^{\circ} \mathrm{C}$ for $24 \mathrm{~h}$. All cultures were done in triplicate. The colonies were then enumerated and the colony forming units (CFU) were calculated per gram of organ and per $\mathrm{mL}$ of blood sample, respectively. The numbers of colonies from the control and the test group were compared using the $t$-test run on the software SPSS for Windows.

\section{Conclusions}

To our knowledge, this is the first detailed in vitro and in vivo study on the anticandidal effects of C. fistula seed extract against $C$. albicans and it revelas that it may be a promising remedy for the development of anticandidal agents in the future. Planned further studies on the activity-directed fractionation for the isolation of respective pure compounds may result in interesting outcomes. 


\section{Acknowledgments}

S. Jothy Lachumy was supported by Universiti Sains Malaysia fellowship from Institute for Postgraduate Studies, Universiti Sins Malaysia.

\section{References and Notes}

1. Trease, G.E.; Evans, W.C. Pharmacognosy, 12th ed.; English Language Book Society: Bailliere Tindall, London, UK, 1985; p. 394.

2. Wallis, T.E. Text Book of Pharmacognosy, 5th ed.; CBS Publishers and Distributors, 485 Jain Bhawan, Shahdara, Delhi, India, 1985; pp. 252-253.

3. Chopra, R.N.; Nayar, S.L.; Chopra, I.C. Glossary of Indian Medicinal Plants, Publication and Information Directorate; CSIR: New Delhi, India, 1992; p. 54.

4. Ekanayake, D.T. Plants used in the treatment of skeletal fractures in the indigeneous system of medicine in Sri Lanka. Srilanka Forester 1980, 14, 145-152.

5. Gupta, M.; Mazumder, U.K.; Rath, N.; Mukhopadhyay, D.K. Antitumor activity of Methanolic extract of Cassia fistula L. seed against Ehrlich Ascites Carcinoma. J. Ethnopharmacol. 2000, 72, 151-156.

6. Luximon-Ramma, A.; Bahorun, T.; Soobrattee, M.A.; Aruoma, O.I. Antioxidant activities of phenolic, proanthocyanidin, and flavonoid components in extracts of Cassis fistula. J. Agric. Food Chem. 2002, 50, 5042-5047.

7. Bhakta, T.; Mukherjee, P.K.; Saha, K.; Pal, M.; Saha, B.P. Hypoglycemic activity of Cassia fistula Linn. (Leguminosae) leaf (Methanol extract) in alloxan-induced diabetic rats. J. Ethnobot. 1997, 9, 35-38.

8. Bhakta, T.; Mukherjee, P.K.; Mukherjee, K.; Banerjee, S.; Mandal, S.C.; Maity, T.K.; Pal, M.; Saha, B.P. Evaluation of hepatoprotective activity of Cassia fistula leaf extracts. J. Ethnopharmacol. 1999, 66, 277-282.

9. PerumalSamy, R.; Ignacimuthu, S.; Sen, A. Screening of 34 Indian medicinal plants for antibacterial properties. J. Ethnopharmacol. 1998, 62, 173-182.

10. El-Saadany, S.S.; El-Massry, R.A.; Labib, S.M.; Sitohy, M.Z. The biochemical role and hypocholesterolaemic potential of the legume Cassia fistula in hypercholesterolaemic rats. Nahrung 1991, 35, 807-815.

11. Esposito Avella, M.; Diaz, A.; De Gracia, I.; De Tello, R.; Gupta, M.P. Evaluation of Traditional medicine: Effects of Cajanus cajan L. and of Cassia fistula L. on carbohydrate metabolism in mice. Rev. Med. Panama 1991, 16, 39-45.

12. Liu, X.; Han, Y.; Peng, K.; Liu, Y.; Li, J.; Liu, H. Effect of traditional Chinese medicinal herbs on Candida spp. from patients with HIV/AIDS. Adv. Dent. Res. 2011, 23, 56-60.

13. Kisangau, D.P.; Lyaruu, H.V.; Hosea, K.M.; Joseph, C.C. Use of traditional medicines in the management of HIV/AIDS opportunistic infections in Tanzania: A case in the Bukoba rural district. J. Ethnobiol. Ethnomed. 2007, 3, 29.

14. Wright, S.C.; Maree, J.E.; Sibanyoni, M. Treatment of oral thrush in HIV/AIDS patients with lemon juice and lemon grass (Cymbopogon citratus) and gentian violet. Phytomedicine 2009, 16, $118-124$. 
15. Lachumy, S.J.T.; Zuraini, Z.; Sasidharan, S. Antimicrobial activity and toxicity of methanol extract of Cassia fistula seeds. Res. J. Pharm. Biol. Chem. Sci. 2010, 1, 391-398.

16. Kuete, V.; Kamga, J.; Sandjo, L.P.; Ngameni, B.; Poumale, H.M.P.; Ambassa, P.; Ngadjui, B.T. Antimicrobial activities of the methanol extract, fractions and compounds from Ficus polita Vahl. (Moraceae). BMC Complement. Altern. Med. 2011, 11, 6.

17. Sasidharan, S.; Yoga Latha, L.; Angeline, T. Imaging in vitro anti-biofilm activity tonvisualize the ultrastructural changes. In Microscopy: Science, Technology, Applications and Education; Méndez-Vilas, A., Díaz, J., Eds.; Formatex: Badajoz, Spain, 2010; pp. 622-626.

18. Booth, I.R. Regulation of cytoplasmic pH in bacteria. Microbiol. Rev. 1985, 49, 359-378.

19. Poolman, B.; Driessen, A.J.M.; Konings, W.N. Regulation of solute transport in Streptococci by external and internal $\mathrm{pH}$ values. Microbiol. Rev.1987, 51, 498-508.

20. Trumpower, B.L.; Gennis, R.B. Energy transduction by cytochrome complexes in mitochondrial and bacterial respiration: The enzymology of coupling electron transfer reactions to trans membrane proton translocation. Ann. Rev. Biochem. 1994, 36, 675-716.

22. Prashar, A.; Hili, P.; Veness, R.G.; Evans, C.S. Antimicrobial action of palmarosa oil (Cymbopogon martini) on Saccharomyces cerevisiae. Phytochemistry 2003, 63, 569-575.

21. Helal, G.A.; Sarhan, M.M.; Abu Shahla, A.N.K.; Abou El-Khair, E.K. Effect of Cymbopogon citratus L. essential oil on growth and morphogenesis of Saccharomyces cerevisiae ML2-strain. J. Basic Microbiol. 2006, 46, 375-386.

22. Latha, L.Y.; Sasidharan, S.; Zuraini, Z.; Suryani, S.; Shirley, L.; Sangetha, S. Antibacterial activity and toxicity of Psophocarpus tetragonolobus. Pharm. Biol. 2007, 45, 31-36.

23. Sasidharan, S.; Darah, I.; Noordin, M.K.M.J. In vitro antimicrobial activity against Pseudomonas aeruginosa and acute oral toxicity of marine algae Gracilaria changii. New Biotechnol. 2010, 27, 390-396.

24. Anaissie, E.; Hachem, R.; K-Tin-U, C.; Stephens, L.C.; Bodey, G.P. Experimental hematogenous candidiasis caused by Candida krusei and Candida albicans: Species differences in pathogenicity. Infect. Immun. 1993, 61, 1268-1271.

Sample Availability: Samples of the extract of $C$. fistula are available from the authors.

(C) 2012 by the authors; licensee MDPI, Basel, Switzerland. This article is an open access article distributed under the terms and conditions of the Creative Commons Attribution license (http://creativecommons.org/licenses/by/3.0/). 